Business Method Patents in Europe and their Strategic Use: Evidence from Franking Device Manufacturers

\author{
Stefan Wagner
}

Discussion paper 2006-15

November 2006

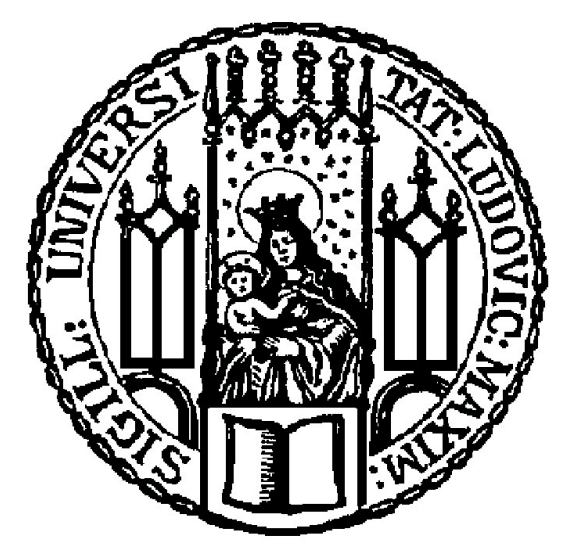

Munich School of Management

University of Munich

Fakultät für

Betriebswirtschaft

Ludwig-Maximilians-Universität München

Online at http://epub.ub.uni-muenchen.de/ 


\title{
Business Method Patents in Europe and their Strategic Use - Evidence from Franking Device Manufacturers
}

\begin{abstract}
There has been a wide-spread misconception based on the imprecise wording of Art. 52 of the European Patent Convention (EPC) that the protection of business methods by patents is prohibited in Europe. This paper investigates the legal framework set by patent laws with respect to the patentability of business methods, contrasting the situation in lege in Europe and the situation in the US. It is shown that in praxi business methods have never been excluded from patentability in Europe. In the empirical part of the paper, 1,901 European patent applications relating to business methods are identified and major patent indicators are computed. Further, a case study from the franking device industry which is characterized by strong competition for intellectual property rights is conducted. It contains evidence for the strategic use of business method patents leading to opposition rates against granted patents of $44 \%$.
\end{abstract}

Keywords: Business Method Patents, Patent Opposition, EPO, Franking Device Manufacturers

JEL Classification: L69, O34 


\section{Introduction}

There has been a wide-spread misconception based on the wording of the European Patent Convention (EPC), which is not easily understood by nonexperts, that the protection of business methods by patents is prohibited in Europe 1 As a consequence, a significant body of the legal, academic and business community believes that there is no patent protection available for business method inventions within the European patent system ${ }^{2}$ However, a closer look reveals that business methods are eligible for patentability in Europe and are actually being granted by the European Patent Office despite the apparent exclusion in Article 52 EPC.

Currently, there is no empirical study to date that focusses on the patentability of business methods in Europe. The purpose of this paper is twofold: First, the legal situation concerning the patentability of business methods in Europe is discussed after summarizing the current debate on the sense and non-sense of patenting business methods. Furthermore, it will be shown that business methods can be patented in Europe, but under somewhat stricter legal conditions than in the US where patents on business methods are granted regularly. The second purpose of the paper is to provide a first empirical look at business method patents in Europe. 1,901 business method patent applications filed at the EPO are identified and analyzed with respect to various patent characteristics. The results are compared to previous findings from a comprehensive study of USPTO business method patents of Allison \& Tiller (2003) revealing that there are no significant differences between the two jurisdictions. Further, a case-study from the industry for franking devices reveals clear evidence for the strategic use of business method patents in Europe. In this industry, one firm relies heavily on business method patents in constructing a large patent portfolio used for bargaining in licensing negotiations. This behavior is part of the intense competition for intellectual property rights in this industry, illustrated by an average opposition rate of $44 \%$ against granted patents.

The remainder of the paper is structured as follows: In section 2, an overview over previous studies of business method patents is given and major concerns about these patents are highlighted. Section 3 contains a short summary of the legal framework with regard to the patentability of business methods in Europe. Section 4 describes the research design applied in this paper and briefly comments on the resulting dataset representing 1,901 European patent applications which are equivalents to granted US business method patents from US patent class 705 . In this section a descriptive analysis of the data with respect to patent characteristics, legal procedures and applicant structure is presented. Section 5 provides evidence for the strate-

\footnotetext{
${ }^{1}$ Compare Art. 52 of the EPC.

${ }^{2}$ For a full treatment of this subject see Beresford (2000).
} 
gic use of business method patents from a case study analyzing their use in the industry for franking devices. Finally, section 6 summarizes the major results and states implications of the findings.

\section{Business Method Patents - A Summary of the Current Debate}

The concept of business methods is notoriously difficult to define. From an economic perspective, the term "business method" is very broad and comprises various economic activities such as selling and buying items, marketing or finance methods, schemes and techniques. From a legal perspective, it is hard to find an abstract definition of what exactly constitutes a business method and what makes it different from other "methods". Currently, neither European nor US (patent) laws contain a legal definition of the term business method while actually using it frequently (Hart et al. 2000).

Only recently have legislators and patent offices in the US and Europe turned their attention to this problem: The European Patent Office (EPO) suggested in one of its publications (which became the basis of the European Commission's software patentability proposal of 2002/02/20) that a business method is any subject matter which is "concerned more with interpersonal, societal and financial relationships, than with the stuff of engineering - thus for example, valuation of assets, advertising, teaching, choosing among candidates for a job, etc... ."However, this coarse definition has not yet been implemented in applicable law.

In the US, a first attempt to define business methods is contained in "The Business Method Patent Improvement Act" which was first proposed to the US congress by Congressmen Berman and Boucher in 2000. The proposal defines a business method as "(1) a method of - (A) administering, managing, or otherwise operating an enterprise or organization, including a technique used in doing or conducting business; or (B) processing financial data; (2) any technique used in athletics, instruction, or personal skills; and (3) any computer-assisted implementation of a method described in paragraph (1) or a technique described in paragraph (2)". The US congress did not accept the proposed bill and therefore current US laws do not contain a legal definition of the term business method yet. Nevertheless, the definition of Berman and Boucher is - at least implicitly - applied in most studies of business method patents and is therefore appropriate for the purpose of this paper.

\section{INSERT FIGURE 1 ABOUT HERE}

During the recent years, there has been a steep increase in applications for business method patents in the sense of this definition in the US (see 
Figure 11) which drew the interest of numerous scholars, from both economics and law, to the business method phenomenon. This resulted in a variety of studies discussing whether business methods should receive patent protection or not and on the consequences which could arise from granting patents on business related ideas. The remainder of this section contains a short summary of the major issues of the current discussion on business method patents, covering quality related issues, examination procedures and welfare implications.

Patent Quality Inventions must satisfy certain criteria in order to be patentable. These are novelty, involvement of an inventive step and industrial applicability. Moreover, invention must not be excluded from patentability due to legal reasons. Additionally to the fulfilment of these criteria, any patent application must disclose details about the invention enabling a third person "skilled in the art" to understand and to implement the invention by studying the patent document. Given these requirements, low patent quality might arise if patents are granted for inventions which do not fully satisfy the patentability criteria or the disclosure requirements (Hall et al. 2003, pp. 2-3). A more detailed discussion of the emergence of low quality patents is contained in National Research Council (2004 pp. 46-63). One of the major allegations against business method patents is the lack of novelty respectively non-obviousness of the protected inventions. Dreyfuss (2000) points to a number of patents which were granted on methods well known to the public before the applicant sought patent protection. Most of the cited patents were involved in invalidity litigation for not satisfying the novelty and the non-obviousness criterion. Dreyfuss (2000) summarizes the interpretations of the novelty and non-obviousness criteria by the judges in the court decisions as follows: "What judges don't understand they think is patentable [...] what judges do understand (or think they should pretend they understand), appears obvious." Bagley (2001) and Lunney (2001) raise further doubts on the quality of business method patents finding that existing inventions and methods are not sufficiently considered in determining the novelty and obviousness of computer-implemented business method inventions. This deficiency gives rise to patents protecting computerized versions of long known business practices $3^{3}$

Deficiencies of examination procedures Most of the described deficiencies of business method patents are attributed to an inadequate examination practice of the responsible patent offices. The major problem identified

\footnotetext{
${ }^{3}$ A good example is Priceline's US patent Nr. 5,794,207 protecting a "Method and apparatus [...] designed to facilitate buyer-driven conditional purchase offers" which protects an internet-based version of the reverse-auction mechanism, where the buyer specifies the product he wants to purchase and the seller offering the lowest price wins the right to deliver the product.
} 
by most observers are problems with the search for prior-art contained in previously issued patents and particularly in non-patent documents. Merges (1999) and Kuester \& Thompson (2001) illustrate a systematic problem with prior art searches in patent databases: Patent examiners at the USPTO look solely at the issued US patents filed prior to the filing date of the application being examined. Before the recent facilitation of obtaining patents on business methods (especially after the State Street vs Signature Financial decision, see section 3) many applications were not filed at all because of the perception that business methods are not patentable. Therefore, most of the prior art was not contained in patent documents which stressed the importance of the search in non-patent documents. However, the search for prior art in non-patent sources is complicated by two facts: First, business methods are rather directly implemented without being documented, making it hard to find any written prior art. Second, Hart et al. (2000) and Hunt (2001) report that patent offices are not provided with appropriate databases for prior art searches in non-patent documents. Their argument suggests that patent examiners can therefore hardly identify existing prior art documents due to limited resources of the patent offices.

Welfare Implications Patents are temporary exclusionary rights which are granted to the inventor in exchange for the publication of a so far unknown invention. If patents are granted erroneously (i.e. patents are granted on inventions and methods which should not be protected by patents), they might be used unwarrantedly to deter entry or induce exit of firms competing with the patent holder by the threat of infringement suits inducing negative welfare effects. In fact, Lerner (1995) has shown that fear of litigation may cause smaller entrant firms to avoid areas where incumbents hold many patents. Since a firm can improve its competitive position by obtaining patents there is an incentive to maximize the size of the patent portfolio at a given level of $R \& D$ effort. This argument is similar to the 'patent portfolio race' in the semi-conductor industry described by (Hall \& Ziedonis 2001).

Furthermore, low quality patents can have a negative effect on social welfare since licensing and litigation costs are increased due to more difficult negotiations when low-quality patents or more patents are involved. For example, numerous and overlapping (in their claims) patents held by different parties make it costly for a potential infringer to bargain a license or even to determine who to bargain with (Heller \& Eisenberg 1998). Additionally, broad and imprecise claims increase the number of potential infringers and therefore the probability of costly litigation. Hall et al. (2003) give a more detailed analysis of welfare implications of patent litigation and the consequences of low-quality patents.

Finally, the granting of low-quality patents might also slow down cumulative inventions as well as the diffusion of new inventions. Meurer (2002) and 
Hall et al. (2003) argue that if previous inventions are protected by patents of dubious quality or excessive breadth, the cost of pursuing inventions relying on them might be discouraging for cumulative inventions. Furthermore, growing numbers of patents might lead to a high degree of fragmentation of property rights protecting previous inventions. This fragmentation might increase the transaction cost of getting access to these technologies (Heller 1998). Hall \& Ziedonis (2001) illustrate this problem of 'patent thickets' in their analysis of the U.S. semiconductor industry.

\section{The Patentability of Business Methods under the European Patent Convention}

While it is widely acknowledged that business methods are patentable subject matter in the US, there has been some confusion as to whether business methods can be patented under the European Patent Convention (EPC) ${ }_{4}^{4}$ Article 52 (2) of the EPC defines which inventions are patentable and explicitly expels business methods from patentability in paragraph (c) by excluding "schemes, rules and methods for performing mental acts, playing games or doing business, and programs for computers" from patentable subject matter. However, according to Art. 52 (3) of the EPC the provisions of paragraph (2) only exclude inventions from patentability "to the extent to which a European patent application or European patent relates to such subject-matter or activities as such". In a series of cases, the Board of Appeal at the EPO concluded that the legislator did not want to exclude all business methods from patentability by combining the two provisions of Art. 52 (2) and (3) EPC and decided that patentability is allowed for - at least - some business methods (Hart et al. 2000).

However, the major problem is to determine which business methods can be protected by patents. Since business methods are excluded from patentability only "as such", a clear definition of what is meant by a business method "as such" is needed for this purpose. Complicating the situation, there is no legal definition of what the "as such"-formulation actually means, leaving it open to interpretation. Hellfeld (1989) gives a comprehensive overview of different interpretations of the "as such"-restriction formed in numerous court decisions and the judicial literature. Because of the unclear meaning of the EPC's "as such"-formulation, the Board of Appeal finally ruled that this criterion cannot be decisive for the distinction between patentable and not-patentable business methods. This view has been

\footnotetext{
${ }^{4}$ In 1998, in the famous State Street Bank and Trust Co. vs Signature Financial Groupdecision involving US patent No. 5,193,056, the United States court of Appeals for the Federal Circuit ruled that business method patents are patentable subject matter (Conley 2003 pp. 21 - 23). See also http://www.law.emory.edu/fedcircuit/july98/96-1327. wpd.html
} 
developed in a series of decisions concerning applications seeking patent protection for business methods and computer programs throughout the 90's (see Hart et al. 2000, Tang et al. 2001).

The criterion developed by the Board of Appeal for the distinction between patentable and non-patentable business methods is the technical character of the underlying invention/ method. However, determining what lends an application of a business method patent the necessary technical character and takes it beyond the exclusion from patentability is extremely difficult. Again, there is no formal definition of this criterion. The relevant decisions of the Board of Appeal on the technical character of business method related patent applications during the 90's (listed in Hart et al. (2000) or also Tang et al. (2001)) can be summarized as follows: A patent application must contain technical considerations either in the underlying problem solved by the claimed invention, the means of solving the underlying problem, or in the technical effects achieved in the solution of the problem. Anders (2001) gives a thorough treatment of what exactly determines the technical character of business related inventions from a legal perspective considering recent developments at the European level. His arguments can be summarized by stating that almost any computer-implemented invention is sufficiently technical making the criteria of novelty and inventive step decisive for a patent grant in Europe (Anders 2001, p. 558). Blind et al. (2003) derive a slightly more restrictive interpretation of the technicality criterion from recent court decisions but admit that patents on computerimplemented inventions are regularly granted by the European patent office.

Meanwhile, the discussion reached policy makers at the European Community level who recently discussed the new EU directive on the patentability of computer-related inventions with direct impact on the regulatory framework of the EPC. The European Parliament decided in a first to maintain and reinforce the exclusion of software and business methods from patentability in September 2003. However, the Council of the Ministers of the European Community voted on March, $18^{\text {th }}, 2005$ in the $2645^{\text {th }}$ meeting on competitiveness of the Council of the European Union for a directive making it possible to patent both software and business methods if they are sufficiently technical (Council of the European Community 2004). Hence, under the current regulation patents on business methods can be granted by the EPO and national patent offices in Europe as long as the underlying invention satisfies the criterion of being sufficiently technical as well as the other criteria of patentability. 


\section{Analysis of European Business Method Patents}

\subsection{Research Design and Data Description}

A variety of empirical studies of US business method patents try to determine whether US business method patents are particular compared to average patents with respect to patent characteristics like quality, scope or value, see for example Allison \& Tiller (2003) or Hunter (2003). These studies do not find clear evidence that business method patents are different from other patents from a statistical point of view. In Europe, there are no comparable studies for business method patents. The only exception that can be found, is in a study by Likhovski et al. (2000) who analyze a set of 300 business method patent applications. However, they present only descriptive statistics of the nationality of the patent applicants in their sample without analyzing further characteristics. In this section, 1,901 European business method patents are identified and analyzed with respect to various patent characteristics. Furthermore, the frequency of legal actions challenging the validity of granted patents within the European opposition system is scrutinized.

Empirical studies of European business method patents are hampered by the fact that there is no simple way to identify business method patent applications at the EPO. Patent applications in other technological areas can be identified rather easily since the EPO classifies all patent applications according to the technological field they belong to for easy retrieval in the future. However, the International Patent Classification (IPC) scheme used by the EPO for this purpose does not contain any subsections devoted to business method patents. Therefore business method patents are classified into a number of different IPC classes which do not exclusively contain business method patents. This classification practice makes it nearly impossible to identify these patents by simply looking at the technological classification provided by the EPO 5

In contrast, the USPTO uses its own classification scheme, which contains a separate class devoted exclusively to business methods. Patent Class 705 entitled as "Data Processing: Financial, Business Practice, Management, or Cost/Price Determination" encompasses machines and methods for performing data processing or calculation operations, where the machine is used in the administration or management of an enterprize, the processing of financial data or the determination of the charge for goods or services (USPTO 1999). The USPTO defines business method patents simply as patents classified in Class 705. It should be noted that the "Business Methods Patent Initiative" announced by the USPTO in 2000 led to a tightening

\footnotetext{
${ }^{5}$ The EPO only recently advocated the introduction of a new class G06Q (which will contain applications related to business methods) in the $8^{\text {th }}$ revision of the IPC forthcoming 2006 (Gianotti 2005).
} 
of the examination procedures for patent applications classified as Class 705 applications in the US. Coincident with the introduction of a second review of the applications as other measures of a more rigorous examination the number of patent grants fell in Class 705 fell sharply in the first quarter of 2000 (National Research Council 2004, p.56). The drop in applications for business method patents (see Figure 1) might be explained by changes in the applicants' filing strategies - trying to avoid Class 705 with their patent applications - due to the policy change of the USPTO.

The strategy for identifying business method patent applications at the EPO pursued in this paper makes use of the fact that these patents can be identified at the USPTO via the US classification rather easily: In a first step, a search in the USPTO's patent database 6 for patents classified in Class 705 was performed yielding the set of granted USPTO business method patents. Using EPO's online database http://ep.espacenet.com, it can be checked whether an application for an equivalent patent had been filed at the EPO 7 The knowledge of existing twin pairs 'EPO-patent - US equivalent' allows to identify all EPO patent applications with an existing US equivalent classified in Class 705. Based on the classification of the USPTO, it can be assumed that the underlying invention of the patent application actually is a business method. Hence, EPO patents with an equivalent USPTO patent in Class 705 will be treated as European business method patents for the remainder of the paper.

While this identification strategy ensures comparability with previous studies of USPTO business method patents (relying also on Class 705 classification), there are selection issues which should be kept in mind when interpreting the results of the following analysis. The USPTO database used for this study contains only granted patents since the USPTO started to publish all patent applications only in November 2000. As a consequence, EPO business method patent applications are only identified if and only if a patent on the underlying invention has been granted in the US. Hence, this design yields only a subset of all existing EPO business method patents. EPO applications with no equivalent application filed in the US or with an equivalent US application which didn't lead to a granted patent are not included in the sample. Therefore a certain share of European business method patent applications is not identified using this strategy and reported figures like the absolute number of applications or patents granted can serve only as lower bound of the unknown number. However, it can be assumed that the likelihood of the existence of international equivalents is an in-

\footnotetext{
${ }^{6}$ USPTO patents are available online at http://www.uspto.gov/patft/index.html latest visit on September, $9^{\text {th }}, 2004$.

${ }^{7}$ If patent protection for a given invention is sought in more than one jurisdiction, the different patents are called equivalent patents. The underlying equivalent definition of the Espace database is that for two documents to be described as equivalents, all their priorities must be the same.
} 
creasing function of the value of a patent. Therefore more valuable patents should be contained in the sample reducing the selection problem. Further, it should be noted that the avoidance of Class 705 after the tightening of the according examination procedures as described above might exacerbate the identification of European business method patent applications for the years after 2000 .

The dataset used in this study was gathered performing a search for US business method patents using the online USPTO database (http: //www.uspto.gov/patft/index.html) on March 1st, 2004 which yielded 8,550 US business method patents in Class 705 . From the publicly available EPO patent database ESPACENET a dataset containing all existing pairs 'EPO patent - equivalent patents' has been constructed on March 3rd, 2004. Matching this dataset with the USPTO business method patents yielded an overlap of 1,901 European patent applications related to business methods with application dates ranging from 1978 to 2002. The data on the 1,901 European 705-equivalents was further augmented to include information on individual patent files from a comprehensive EPO patent dataset previously described by Harhoff \& Wagner (2005).8 The resulting dataset contains information on the patent applicant, the application procedure, patent characteristics as well as information on post-grant opposition.

\subsection{Applications and Applicants of Business Method Patents at the European Patent Office}

Table 1 gives an overview of the nationalities of applicants. At the EPO level, European applicants are responsible for about $23 \%$ of all applications for business method patents. American applicants file more than $56 \%$ of all applications for business method patents in Europe. This result is in line with previous findings of Likhovski et al. (2000). The dominance of US applicants in the field of business method patents in Europe is remarkable as US applicants are responsible for only $29 \%$ of all patent applications at the EPO.

\section{INSERT TABLE 1 ABOUT HERE}

\section{INSERT FIGURE 2 ABOUT HERE}

Figure 2 illustrates the yearly number of applications broken down by the origin of the patent applicant distinguishing applicants from Europe, the US and Japan. It is striking that the recent growth of business related patent applications starting in the first half of the 90's was largely driven by the tremendous growth of American applications quadrupling between

\footnotetext{
${ }^{8}$ This database contains extensive bibliographic and procedural information on patent applications published by the EPO between 1978 and 2003.
} 
1993 and 1998; filings from Europe and Japan merely doubled in the same period. It seems likely that the steeper increase of US business method patent applications in Europe is a direct consequence of the higher awareness of the availability of business method related patents in the US due to widely noted court decisions in validity and enforcement cases. This hypothesis is supported by the fact that the strong growth of US applications relative to other nations appeared at the same time as the simplification of the US laws concerning business method patents.

Table 2 shows the distribution of the outcomes of the application procedures. The comparison of the applications for business method patents with the total population of all 1,266,506 patent applications filed at the EPO reveals only minor differences in the overall outcomes of the application procedures. While the grant rate is slightly higher for business related patent applications, the inverse is true for the share of patents which have been withdrawn by the patent applicant before a final decision by the EPO was published (see Table 2). Discriminating patent applications by the origin of their applicant reveals some differences across countries (see Table 1): While European and Japanese patent applications are characterized by an above-average success-rate of $74.67 \%$ and $81.25 \%$ of all applications leading to patents, attempts of US applicants were successful in only $59.60 \%$ of all filings. The phenomenon of lower success rates of US applicants is not confined to business methods but can be found over all patent applications with grant rates of about $55.70 \%$ for US applicants.

\section{INSERT TABLE 2 ABOUT HERE}

Table 3 lists the 14 most active applicants for business method patents at the EPO. They account for more than $40 \%$ of all identified applications. Column 3 of Table 3 contains the number of all applications filed (including pending cases) and the number of granted patents can be found in column 4 . Most of these applicants are multinational corporations from technological fields such as consumer electronics, computer technology and telecommunications which patent a variety of different business methods. However, three of the top five applicants are exceptions in their size and technological focus of their operations: Being concentrated on a narrow business field, Pitney Bowes, Frankotyp-Postalia and Neopost Ltd. are specialists in the niche for mailroom technology like franking or inserting machines and service providers for mail processing in companies. The patenting activities of these three firms largely focus on advanced methods for electronic franking devices e.g. a "method for billing despatch services" (EP19980250253, Frankotyp-Postalia). In total, they account for more than $15 \%$ of all applications for business method patents making mailroom technology one of the biggest single technology clusters within the field of business methods. In fact, the respective IPC-class G07B17/00-04 "Franking apparatus" contains 
$19.57 \%$ of all business method patents identified, most held by the three firms.

\section{INSERT TABLE 3 ABOUT HERE}

\subsection{Patent Characteristics}

During the last decade, researchers started to employ characteristics of the individual patent both in theoretical and empirical studies to explain industrial structures and strategic behavior of firms introducing measures for the value, the breadth or the generality of a single patent. Allison \& Tiller (2003) use different patent indicators in their study of 1,093 USPTO internet business method patents for analyzing major differences between business method patents and the average USPTO patent in order to determine whether business method patents are of minor quality. Based on their findings that business method patents tend to cite more prior art than the average patent, they suggest that the selection of business method patents used in their study is no worse than the average patent. This finding is supported by the study of Hunter (2003). In this section, the most important patent characteristics are computed for European business method applications and are compared to the corresponding figures of the population of all EPO patent applications.

An important procedural characteristic of patent applications is the duration of the examination period at the patent office. From a firm's perspective, this period is characterized by uncertainty over getting the patent finally granted, which might determine the timing and volume of subsequent investments in production facilities. From a regulator's view, longer examination times might decrease the rate of erroneous grant decisions increasing average patent quality and overall welfare. A more elaborate treatment of these issues is contained in Harhoff \& Wagner (2005). Column 1 of Table 4 contains a brief overview of the mean examination times for business method patents compared to the overall means for the years 1978 to 2000 . The examination of business method patents takes almost a year longer compared to the average examination time for all patent applications at the EPO. However, there are several potential explanations for the longer examination times in the case of business method patents: For instance, business method patent applications could in general be more thoroughly examined as compared to other patents. Another explanation could be that the examination is more time-consuming due to higher complexity involved. Indeed, it is shown below that business method patents are characterized by a high number of claims. A third - and probably the most likely - explanation might be a shortage of examiners capable of reviewing business method patent applications. 


\section{INSERT TABLE 4 ABOUT HERE}

As shown in section 2, it is widely believed that business method patents are granted with (too) little attention to the existing prior art. During the examination of patent applications, prior art in the form of patents and other printed publications (non-patent references) describing the related technological advances is referenced by both the applicant and the examiner in order to determine the scope of the existing prior art. Columns 2 and 3 of Table 4 show the average number of cited patents and cited non-patent documents in both business method and all patent applications. Contrasting the expectation that business method related applications fail to cite prior art, it can be seen that business method related applications on average cite more prior patents than the total average. Concerning references to non-patent documents, business method patents do not cite less than the average patent, but slightly more. These finding are in line with the results for USPTO patents in Allison \& Tiller (2003) and Hunter (2003).

The number of citations a patent receives by subsequent patents (forward citations) is generally interpreted as an indication that it has contributed to the state of the art. Previous studies have found a positive correlation with the monetary value of the patent (see Harhoff et al. (1999) and Lanjouw \& Schankermann (2001)). The reported numbers of citations (see Table 4 Column 7) are computed within the EPO system. Only citations received from subsequent EPO patents are identified. It is striking that business method patents receive on average two times more citations than the average patent. There are at least two potential explanations for this phenomenon: First, it could be argued that due to the comparably low number of business method patents relevant prior art for subsequent patents is contained in only few documents, which are cited frequently. Second, the high number of citations might also indicate that those patents are more valuable for the patent holder than average patents. However, whether the patent holder is able to extract higher monetary value from business method patents or not is not clear and requires a more thorough analysis.

The claims contained in a patent file delineate the boundaries of the property rights granted to the patent applicant by describing unique features of the underlying invention which are protected by the patent. Column 4 of Table 4 clearly shows that the number of claims in a business method patent is considerably higher for business method patents than for the average patent. The yearly breakdown shows that the gap between business method and average patents increased considerably over the nineties. The economic interpretation of the total number of claims is not straight forward. On the one hand, it can be argued that each additional claim raises the probability of an infringement. On the other hand, each additional claim in a patent makes the description of the claimed invention more specific and therefore 
narrows the scope of the protected area (see Lanjouw \& Schankermann (2001) for a discussion of this trade-off).

A further characteristic of a European patent is the number of designated states. As any EPO patent becomes a bundle of national patent rights once it is granted, each applicant has to specify the countries in which he wants to obtain patent protection. The more countries designated in an application, the higher the resulting fees for keeping the patent alive in each designated country. Harhoff et al. (2003) showed that the number of designated countries is correlated with the patent value, while Guellec \& Pottelsberghe (2000) came to more ambiguous findings. Applications for business method patents designate only slightly more countries than the average implying that there is no big systematic difference between business method patents and other patents.

The analysis of major patent characteristics reveals that business method patents contain a higher number of claims, cite more patents as well as nonpatent documents and are cited by subsequent patents more frequently than the average patent. This result does not support the hypothesis that business method patents are of lower quality than other patents - at least if the criteria analyzed above are interpreted as indicators of patent quality. The findings presented here are in line with the study of USPTO business method patents of Allison \& Tiller (2003). However, it should be kept in mind that this data cannot answer some important questions. It is unclear whether nonpatented prior art in the area of business methods is so diverse that examiners still miss the greatest part of it or if the examinations process overlooks some business methods which are in common use but not documented in written sources (National Research Council 2004, p. 50).

\subsection{Post-Grant Opposition Procedures}

The opposition system implemented at the EPO is a post-grant procedure which allows third parties to challenge the validity of granted patents directly at the EPO without taking the risk of an expensive suit before courts. This procedure is less costly and more efficient than a pure court-based litigation system as it is implemented in the US patent system. A detailed comparison of the European and the US patent litigation system can be found in Hall et al. (2003). Given the controversial debates on the patentability of business methods and the fear of negative consequences from doing so, it is a plausible assumption that this institution is used more frequently in the sector of business methods than in other technological areas.

\section{INSERT TABLE 5 ABOUT HERE}

Table 5 supports the hypothesis that business method patents are more frequently challenged than the average patent: 108 patents $(16 \%)$ of all 
granted business method patents have been challenged compared to only $39.161(6 \%)$ of all patents at the EPO. Table 5 illustrates that, additionally to higher opposition rates, opposed business method patents are more frequently revoked by the EPO than other patents. More than $41 \%$ of the opposed business method patents are declared invalid, while the according level in the population is $36 \%$. In general, oppositions lead to the revocation of a patent if the opponent reveals new information which has not been considered in the grant decision and which prohibits the granting of a patent. A higher revocation rate for business method patents could therefore be interpreted as an indication that the EPO is not able to gather information during the examination of business method patents as efficiently as in other technological areas.

A closer look at these oppositions reveals that more than $60 \%$ of all oppostions are filed in IPC group G07 "Checking Devices" which contains only $40 \%$ of all granted patents leading to an above average opposition rate of almost $25 \%$ in this IPC group. Excluding IPC group G07 from the sample reduces the overall opposition rate against business method patents to 9.80\%. The subgroup G07B17 "Franking Devices" exhibits an extraordinary opposition rate of more than $40 \%$ of all granted patents. As subsection 4.2 revealed, almost all patents in this group belong to only three applicants (Pitney Bowes, Frankotyp-Postalia and Neopost). The high concentration of granted patents in this technological area among only three patent holders and the intense opposition activity makes the area of "Franking Devices" an interesting research topic. Due to the limited number of players, individual IP strategies can easily be analyzed. The following subsection contains a detailed analysis of this technological area with special attention on the use of business method patents.

\section{Strategic Use of Business Method Patents: The Case of Franking Machines}

\subsection{Market-Structure}

The previous sections have shown that the identified business method patents differ from the average EPO patent with respect to important patent characteristics. Additionally, one industrial sector turned out to be rather exceptional with respect to the intensity of competition for intellectual property rights: the business for franking devices and mailroom technology. This section briefly analyzes the industrial structure of this market and sheds some light on the patenting strategies of the involved firms. This industry is a good example for the strategic use of patents, as it is characterized by a relatively strong litigation activity - if opposition cases at the EPO are considered as an indicator for litigation. A similar study for the cosmet- 
ics and toilet preparations industry can be found in Hall \& Harhoff (2002). However, this brief study is different from their work as it focuses in particular on the strategic use of business method patents. It uses a second dataset which is not restricted to business method patents identified in the previous Section but contains all EPO patents of the major competitors in the market for franking devices.

The basic function of a postal franking machine is to print a mark recording the payment of postage on an envelope or label and to record the amount of postage paid. A franking machine basically consists of a meter which securely records the amount of postage used and a base which handles the passage of envelopes through the meter. Apart from just paying the right postage, franking machines also provide a wider range of services making them central to any modern mailing services. Up-to-date franking machines include computerized accounting tools, which allows for efficient cost control, making it possible to track mail conveniently. The latest technological developments in franking devices can be found in the sector of two-dimensional barcoding and the emergence of internet-based franking tools allowing users to pay postage online and simply print the required stamps with any office printer. As franking machines and other means of getting postage are in effect means to print money, their production, circulation and use are tightly regulated by postal authorities. Manufacturers and independent firms wishing to service franking machines and similar devices must be approved by national agencies.

Currently, there are five important manufacturers for franking devices (Competition Commission 2002). However, the market is controlled by only three major competitors serving an estimated $94 \%$ share of the total market according to the British Competition Commission (Competition Commission 2002). With a world-wide market share of $62 \%$, Pitney Bowes (USA) is by far the largest enterprise, followed by its smaller competitors Neopost (GB) - the latter acquired the Swiss manufacturer Ascom in 2002 and Frankotyp-Postalia (Germany) with market shares of $22 \%$ and $10 \%$ (Competition Commission 2002) respectively. In the US, Pitney Bowes is notorious for the aggressive use of its intellectual property rights from a settlement with Hewlett Packard on a US patent infringement suit including a far reaching cross-licensing agreement and the payment of 400 Mio. USD to Pitney Bowes in 2001. While the patent under dispute in this case was related to a technological feature of laser printers, more recently Pitney Bowes settled an infringement case involving business method patents (US patents No. 5,448,641 and 5,742,683) with the major providers for internet-based postage systems Stamps.com and E-stamps.com. The settlement included a five-year cross-licensing agreement allowing Pitney Bowes to access patents for online franking systems owned by Stamps.com and E-stamps.com. Both patents mentioned in the infringement case are classified in US Class 705 (business methods) and there exist granted equivalents at the EPO. 
It is unclear whether such patents could be enforced in European courts, but at least they cause additional uncertainty for Pitney Bowes' competitors. In fact, in their report on the merger of two of Pitney Bowes' competitors Neopost and Ascom - the British Competition Commission noted that the size of Pitney Bowes' patent portfolio and its willingness to enforce its IPRs rigorously causes major difficulties for its competitors in the development of new products - both in Europe and the US. They either have to avoid patent infringement by inventing around Pitney Bowes' patents or at least to limit the cost of licensing where licenses are required. These difficulties led Neopost to enter a world-wide cross-licensing agreement with Pitney Bowes under undisclosed terms (Competition Commission 2002).

\subsection{Patent Strategies}

In order to fully understand the patenting behavior of the competitors in this field, a particular dataset has been constructed for this chapter. This dataset contains all EPO patents held by franking device manufacturers and is not restricted to the 705 equivalents identified in the previous section. In total, this dataset comprises 588 patents (thereof 157 patents related to business methods, see Table 6).

\section{INSERT FIGURE 3 ABOUT HERE}

Figure 3 shows the cumulative number of granted patents at the EPO. This figure can be interpreted as a rough estimation of the size of the patent portfolio of the individual firms 9 As one can see, Pitney Bowes started to patent in the early eighties, much earlier than its competitors who started patenting only about five to ten years later. As a consequence, it currently holds a patent portfolio which is almost threefold the portfolio of its second biggest competitor, Neopost.

\section{INSERT TABLE 6 ABOUT HERE}

Table 6 summarizes the size and the composition of the patent portfolios with respect to the share of existing US equivalent patents in general and the share of business method patents (granted patents with an US equivalent classified in Class 705) in particular. In total, Pitney Bowes is the most important patentee, holding $312 \mathrm{EPO}$ patents. The share of existing US equivalents to European patents (appr. 79\%, see Table 6, Column 3) is roughly identical for Pitney Bowes, Neopost and Frankotyp-Postalia, indicating that the three firms pursue similar patenting strategies in terms of

\footnotetext{
${ }^{9}$ Cumulating the number of granted patents overestimates the actual size of the patent portfolio since patents might lapse due to the non-payment of renewal fees and since patents can be revoked in opposition proceedings.
} 
obtaining international protection for their IPs. However, differences among the firms emerge in the reliance on business method patents as part of their patenting strategies. The share of business method patents in the patent portfolio of Pitney Bowes is highest with $31 \%$ of all patents followed by Neopost with 19\%; Frankotyp-Postalia holds only one in ten of its patents on a business method related invention.

In general, the opposition rate against patents held by franking device manufacturers is above average with $28 \%$ of all patents granted (compared to about $6 \%$ for the total population). Further, big differences in the opposition rates can be observed on the firm-level: While on average only $5 \%$ of Frankotyp-Postalia's patents are opposed, almost $41 \%$ of all patents granted to Pitney Bowes are opposed. Additional to these firm level differences, business method patents (patents with an US equivalent filed in class 705) are opposed more frequently than other patents in general and across firms. Particularly interesting is the high rate of opposition against Pitney Bowes' business method patents, which are opposed in two of three cases.

\section{INSERT TABLE 7 ABOUT HERE}

Finally, Table 7 crosstabulates opposing against opposed parties, focussing on the most active opponents and the holders of the biggest portfolios of European business method patents. The second column of Table 7 depicts the total number of oppositions filed against business method patents for each opponent. Additionally, the total number of all oppositions filed (i.e. independently of the technological area of the opposed patent) is given in brackets. For example, Frankotyp-Postalia filed 38 oppositions against business method patents held by Pitney Bowes and 90 oppositions against Pitney Bowes in total. Focusing on the four firms from the franking device industry (Frankoty-Postalia, Neopost, Pitney Bowes and Societé Secan ${ }^{10}$ ) reveals some interesting differences in their IP strategies: Pitney Bowes is attacked by most of its competitors very aggressively, although it hardly uses the opposition mechanism itself. In fact, all oppositions filed by FrankotypPostalia and Neopost and almost all of Sc. Sécap's oppositions are targeted exclusively against patents held by Pitney Bowes. In contrast, Pitney Bowes only files only few oppositions against patents held by its direct competitors.

Combining the findings of this subsection, it becomes clear that Pitney Bowes' IP strategy is focused on building a very broad patent portfolio and the aggressive enforcement of its IPRs in case of infringement. The numerous cross-licensing agreements between Pitney Bowes and its rivals highlight this strategy and provide evidence that the patent portfolio is used as a bargaining chip in licensing negotiations. The attempt to build a very broad

\footnotetext{
${ }^{10}$ Societé Secap is a small manufacturer for franking devices with a negligible market share and no own patenting activities.
} 
patent portfolio relies heavily on the filing of business method patents. As a consequence, competitors try to bar Pitney Bowes from further increasing its portfolio by opposing Pitney Bowes patents frequently. Even if those oppositions are only of average success (they do not lead to the revocation of the opposed patent more frequently than the average opposition), they lead to a comparatively high ratio of revoked patents relative to the number of granted patents. This can be interpreted as a sign for an below-average quality of Pitney Bowes patent applications and is especially true for business method patents, which are opposed at the rate of $60 \%$.

These findings support some of the concerns against business method patents raised in section 2 of this paper. At least in the industrial sector of franking devices, business method patents seem to be an integral part of an IP-strategy which consists of building patent portfolios as large as possible serving to increase the bargaining power of its holder in cross-licensing negotiations or in order to reduce competition in the market. A strategy well described in Shapiro (2001). This supports the raised concerns that business method patents can be used or misused for exclusionary purposes. Further, the high litigatious activity in terms of oppositions taking place (which is above average if business method patents are involved) leads to high costs associated with the legal proceedings taking place. Finally, the report of the British Competition Commission contains evidence, that the existence of Pitney Bowes' patent portfolio raises uncertainty for its competitors in the product development process which slows down innovation.

\subsection{Multivariate Analysis of Opposition against Patent Grants}

In this section simple probability models of the incidence of an opposition occurring against patents granted to the five franking device manufacturers are estimated in order to explore how the pattern of opposition is related to a variety of patent characteristics. Following similar studies of Harhoff \& Reitzig (2004) and Harhoff et al. (2003), the occurrence of opposition is regressed on most of the characteristics presented in Section 4.2 (the number of claims, the number of references to patent and non-patent literature, the number of designated states, and the number of forward citations received within five years after application). Special attention is given to the industrial structure by the introduction of dummy variables coding the five patent applicants (using Pitney Bowes as reference group). Moreover the analysis distinguishes whether a patent is related to a business method and whether a US equivalent patent is existing or not.

In addition, several control variables are included in the models: Generality and originality measures proposed by Trajtenberg et al. (1997) are citation-based indices which measure different aspects of the patented innovation and their links to other innovations. The generality index is high if a patent is cited by subsequent patents that belong to a wide range of fields 
and low if most referring citations are concentrated in a few fields. Hence, a high generality index suggests that the patent influenced subsequent innovations in a variety of different fields and is more general. The originality index indicates, whether a patent cited only patents from a wide or from a narrow set of technologies. Additionally, the share of citations defining the general state of the art, which is not considered to be of particular relevance (type A citations), and the share of citations indicating that the claimed invention cannot be considered to be novel or to involve an inventive step (type $\mathrm{X}$ citations) is included. A detailed description of the use of patent citations in economic analysis can be found in Michel \& Bettels (2001). The number of different IPC classifications of a patent (as introduced by Lerner 1994) can be seen as a correlate for patent value and is contained in the estimations. Finally, a set of dummy variables indicating whether the patent application was filed before 1985, between 1985 and 1989, 1990 and 1994, or 1995 and after is included in order to capture responses to the changing legal environment and unobserved economic fluctuations over the last decades (patents with application dates later than 1995 are the reference group). Further, dummy variables indicating the patentee are introduced in order to capture firm-specific effects (Pitney Bowes is the reference group). The data set has been restricted to patents with application dates prior to 1998, yielding in total 544 patents, since forward citations received within five years after application are included in the regression.

\section{INSERT TABLE 8 ABOUT HERE}

Table 8 contains the results of a multivariate probit analysis. The first specification (Column 1) contains a basic model including only patent characteristics and time dummies. Previous results of Harhoff \& Reitzig (2004) are confirmed: The probability of an opposition occurring is increased by the total number of patent references contained in the document and the corresponding share of X citations. Furthermore, the value correlates carry a positive sign - but only the number of different IPC classifications has a significant influence. Patents with application dates prior to 1996 are more likely to be opposed with a maximum increase in the opposition probability between 1990 and 1995. This phenomenon might reflect reactions of the firms to a more benign legal climate with respect to the patentability of business methods after 1995. An alternative explanation might be seen in changes of the patenting strategy of the firms in the market: Realizing the importance of intellectual property protection only at the end of the eighties and the beginning nineties (see Figure 3), Pitney Bowes' competitors might have pursued a defensive patent strategy, trying to oppose Pitney Bowes' patents before finally changing to an active filing strategy in the 90s. These results are robust to different model specifications.

Columns 2 and 3 of Table 8 contain additional dummy variables of the 
existence of a US equivalent patent and business method patents. They indicate that business method patents are about $15 \%$ more likely to be opposed, compared to non-business method patents. Finally, Column 4 contains the results of a specification including additional dummy variables for each firm, using Pitney Bowes as the reference group. The result that business method patents are more likely to be opposed (the probability of the occurrence of opposition taking place is increased by almost $15 \%$ if business method patents are involved) remains rather stable after controlling for the identity of the patent holder, too. Furthermore, patents owned by Pitney Bowes' competitors are significantly less likely to be opposed. The probability that patents by Frankotyp-Postalia, Neopost and Ascom are opposed is about 20\% lower compared to Pitney Bowes. This is a consequence of the fact that Pitney Bowes patents are more disputed than other patents, as described in the previous subsection, reflecting the averting strategies of Pitney Bowes' competitors.

\section{Conclusion}

The discussion on business method patents mainly focusses on the US patent system, implicitly assuming that business method patents are not granted to a relevant extent in Europe. This assumption is mainly based on the misconception that business method patents are excluded from patentability in Europe. However, they are admissible legally and a closer look reveals that business method patents are actually being granted by the European Patent Office. A sample of 1,901 patent applications relating to business methods has been identified in this paper. The analysis of patent characteristics for this sample yielded mixed evidence concerning the potentially low quality of business method patents. Compared to the average of all European patent applications, they cite slightly less previous patents but more non-patent documents and receive a significantly higher number of forward citations. Additionally, business method patents are characterized by a longer examination period. However, the long pendency in examination is more likely to be caused by a shortage of examiners in the field than by an above-average examination accuracy. More important, business method patents are more often revoked than other patents, when legally challenged in opposition proceedings at the EPO. This is an indication that the EPO is not able to gather prior art as efficiently as in other technologies (despite the higher number of references business method patents contain).

Further, a micro-level analysis of the industry for franking devices yielded insights in the strategic use of business method patents, supporting some of the concerns raised against the patentability of business methods. In this industry, one firm relies heavily on business method patents in order to construct a large patent portfolio. This behavior induces its competitors 
to fight back by opposing against its patents at an enormous frequency. In fact, more than $40 \%$ of its patents are opposed overall and $60 \%$ of its patents on business methods are attacked by competitors. A multivariate analysis of the occurrence of opposition proceedings taking place in this industry revealed that the probability of an opposition occurring is actually about $15 \%$ increased for business method patents even after controlling for patent characteristics and the identity of the patent holder. This finding illustrates that business method patents are more controversial than other patents. The findings from this case study therefore support the concerns that the granting of business method patents might lead to inefficiently high litigation cost.

\section{References}

Allison, J. R. \& Tiller, E. H. (2003), 'The Business Method Patent Myth', Berkeley Technology Law Journal 18, 5-27.

Anders, W. (2001), 'Wie viel technischen Charakter braucht eine computerimplementierte Geschäftsmethode, um auf erfinderischer Tätigkeit zu beruhen?', Gewerblicher Rechtsschutz und Urheberrecht pp. 555-560.

Bagley, M. A. (2001), 'Internet Business Model Patents: Obvious by Analogy', Michigan Telecommunications and Technology Law Revue 7, 253288.

Beresford, K. (2000), Patenting Software under the European Patent Convention, Sweet \& Maxwell, London.

Blind, K., Edler, J., Nack, R. \& Straus, J. (2003), Software-Patente Eine empirische Analyse aus ökonomischer und juristischer Perspektive, Phyisca-Verlag, Heidelberg.

Competition Commission (2002), Neopost SA and Ascom Holding AG: A report on the proposed merger, Report 465, United Kingdom Competition Commission.

Conley, J. M. (2003), 'The International Law of Business Method Patens', Federal Reserve Bank of Atlanta Economic Review pp. 15-33.

Council of the European Community (2004), Proposal for a Directive of the European Parliament and of the Council on the patentability of computerimplemented inventions - presidency compromis proposal, 5570/04, Council of the European Community, Brussels.

Dreyfuss, R. C. D. (2000), 'Are Business Method Patents Bad for Business', Santa Clara Computer and High Technology Law Journal 16, 263-278. 
Gianotti, L. (2005), Business Methods, E-Commerce, and Finance, SR-Brief 7/2005, European Patent Office.

Guellec, D. \& Pottelsberghe, B. v. (2000), 'Applications, Grants and the Value of Patents', Economic Letters 69(1), 109-114.

Hall, B., Graham, S., Harhoff, D. \& Mowery, D. (2003), Prospects for Improving U.S. Patent Quality via Post-grant Opposition, Working Paper 9731, NBER.

Hall, B. \& Harhoff, D. (2002), Intellectual Property Strategy in the Global Cosmetics Industry, Working paper, University of Munich, Munich.

Hall, B. \& Ziedonis, R. (2001), 'The Determinants of Patenting in the U.S. Semiconductor Industry, 1980-1994', RAND Journal of Economics 32(1), 101-128.

Harhoff, D., Narin, F., Scherer, F. \& Vopel, K. (1999), 'Citation Frequency and the Value of Patented Innovation', Review of Economics and Statistics 81(3), 511-515.

Harhoff, D. \& Reitzig, M. (2004), 'Determinants of Opposition against EPO patent grants - the Case of Biotechnology and Pharmaceuticals', International Journal of Industrial Organization 22(4), 443-480.

Harhoff, D., Scherer, F. \& Volpel, K. (2003), 'Citations, Family Size, Opposition and the Value of Patents Rights', Research Policy 32(8), 1343-1363.

Harhoff, D. \& Wagner, S. (2005), Modelling the Duration of Patent Examination at the European Patent Office, Discussion Paper 5283, CEPR, Munich.

Hart, R., Holmes, P. \& Reid, J. (2000), The Economic Impact of Patentability of Computer Programs, Report to the European Commission, OECD.

Heller, M. A. (1998), 'The Tragedy of the Anticommons: Property in the Transition from Marx to Markets', Harvard Law Revue 11, 621-688.

Heller, M. A. \& Eisenberg, R. S. (1998), 'Can Patents Deter Innovation? The Anticommons in Biomedical Research', Science 280, 248-271.

Hellfeld, A. v. (1989), 'Sind Alghorithmen schutzfähig?', Gewerblicher Rechtsschutz und Urheberrecht pp. 471-485.

Hunt, R. (2001), 'You can patent that? Are Patents on Computer Programs and Business Methods Good for the New Economy', Federal Reserve Bank of Philadelphia Business Review pp. 5-15. 
Hunter, S. (2003), Have Business Method Patents gotten a Bum Rap? Some Empirical Evidence, Working Paper 182, Center for eBusiness@MIT, Boston.

Kuester, J. \& Thompson, L. E. (2001), 'Risks Associated with Restricting Business Method and e-Commerce Patents', Georgia State University Law Review 17, 657-689.

Lanjouw, J. O. \& Schankermann, M. (2001), 'Characteristics of Patent Litigation: A Window on Competition', RAND Journal of Economics 32(1), 129-151.

Lemley, M. A. (2001), 'Rational Ignorance at the Patent Office', Northwestern University Law Review 95(4), 21-56.

Lerner, J. (1994), 'The Importance of Patent Scope: An empirical Analysis', RAND Journal of Economics 25(2), 319-333.

Lerner, J. (1995), 'Patenting in the Shadow of Competitors', Journal of Law and Economics 38(2), 1495-1496.

Likhovski, M., Spence, M. \& Molineaux, M. (2000), The First Mover Monopoly - A study on patenting business methods in Europe, Working paper, Olswang and Oxford Intellectual Property Centre, Oxford University.

Lunney, G. S. (2001), 'E-Obviousness', Michigan Telecommunications and Technology Law Revue 7, 363-422.

Merges, R. P. (1999), 'As Many as Six Impossible Patents before Breakfast: Property Rights for Business Concepts and Patent System Reform', Berkeley Technology Law Journal 14, 577-615.

Meurer, M. (2002), 'Business Method Patents and Patent Floods', Washington University Journal of Law and Policy 8, 309-340.

Michel, J. \& Bettels, B. (2001), 'Patent Citation Analysis - A closer Look at the Basic Input Data from Patent Search Reports', Scientometrics 51(1), 185-201.

National Research Council (2004), A Patent System for the $21^{\text {st }}$ Century, The National Academies Press, Washington, D.C.

Shapiro, C. (2001), Navigating the Patent Thicket: Cross Licenses, Patent Pool, and Standard Setting, Vol. 1 of Innovation Policy and the Economy, MIT Press.

Tang, P., Adams, J. \& Paré, D. (2001), Patent Protection of Computer Programs, Report to the European Commission, European Commission. 
Trajtenberg, M., Henderson, R. \& Jaffe, A. (1997), 'University versus Corporate Patents: A Window on the Basicness of Invention', Economics of Innovation and New Technology 5, 19-50.

USPTO (1999), Automated Financial or Management Data Processing Methods (Business Methods), White paper.

Wright, B. C. (2002), 'Business Method Patents: Are There any Limits?', J. Marshall Review of Intellectual Property Law 2, 30-56. 


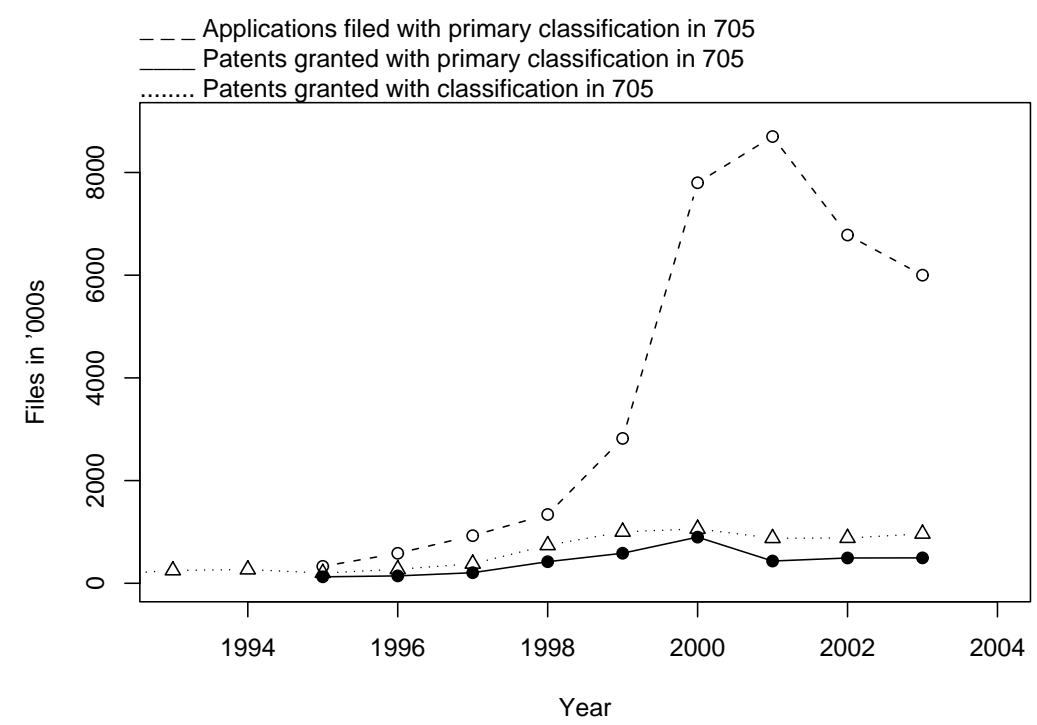

Figure 1: USPTO business method patent applications and grants. (Note that applications do not include Continued Prosecution Applications and Requests for Continued Examination.) Source: Own calculations and USPTO, http://www.uspto.gov/web/menu/pbmethod/ applicationfiling.htm, latest visit on September, $9^{\text {th }}, 2004$.

\begin{tabular}{|c|c|c|c|c|c|c|c|c|c|c|}
\hline EPO & \multicolumn{8}{|c|}{ Origin of EPO Patent Applicant } & \multirow{2}{*}{\multicolumn{2}{|c|}{ Total }} \\
\hline Outcome & & rope & & pan & & $\mathrm{A}$ & & ther & & \\
\hline pending & 137 & - & 141 & - & 587 & - & 21 & $-c_{-}$ & 886 & - \\
\hline grant & 224 & $74.67 \%$ & 156 & $81.25 \%$ & 295 & $59.60 \%$ & 14 & $50.00 \%$ & 689 & $67.89 \%$ \\
\hline withdrawal & $\begin{array}{l}59 \\
17\end{array}$ & $\begin{array}{l}19.67 \% \\
5.67 \%\end{array}$ & 32 & $\begin{array}{c}16.67 \% \\
2.08 \%\end{array}$ & $\begin{array}{c}172 \\
28\end{array}$ & $\begin{array}{l}34.75 \% \\
5.66 \%\end{array}$ & $\frac{12}{2}$ & $42.86 \%$ & 275 & $\begin{array}{r}27.09 \% \\
5.02 \%\end{array}$ \\
\hline Total & 437 & $100 \%$ & $\overline{333}$ & $100 \%$ & $\overline{1.082}$ & $100 \%$ & $\overline{\overline{49}}$ & $100 \%$ & $\overline{1,901}$ & $100 \%$ \\
\hline
\end{tabular}

Table 1: Outcomes of application procedures by applicants' country of origin $1978-2003$.

In a Pearson $\chi^{2}$-test the differences between the applicant groups turned out to be significant at the $1 \%$ level $\left(\chi^{2}(6)=46.40\right.$ excluding pending cases, $\chi^{2}(9)=117.24$ including pending cases $)$. 


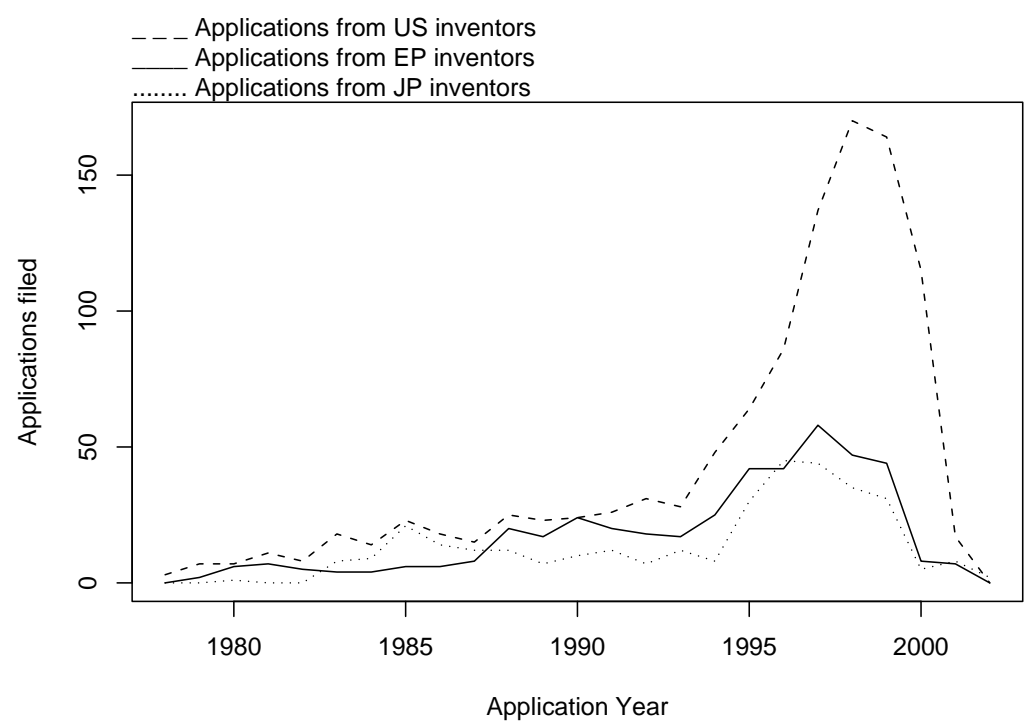

Figure 2: Number of applications for business method patents filed by application year and country of origin of the inventor.

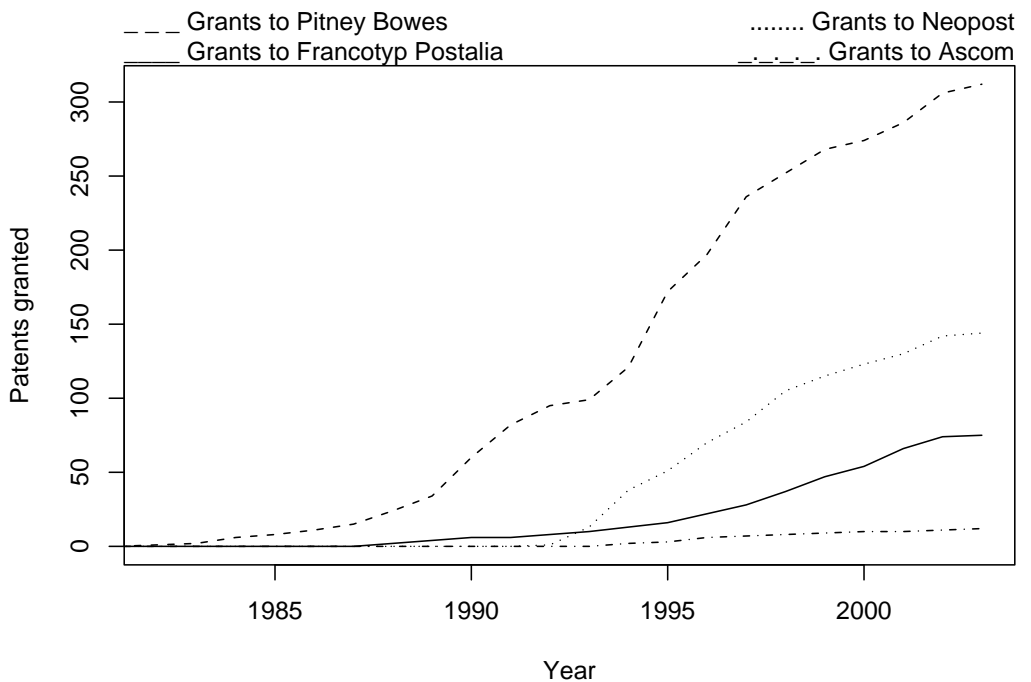

Figure 3: Cumulated European patent grants for major competitors in the market for franking devices. 


\begin{tabular}{r||cc|cc}
\hline \multicolumn{1}{c||}{ Outcomes of Application } & \multicolumn{2}{c|}{ BMP } & \multicolumn{2}{c}{ Total } \\
Procedures & Cases & Percent & Cases & Percent \\
\hline Application pending & 886 & - & 330,673 & - \\
\hline Patent granted & 689 & $67.88 \%$ & 606,967 & $64.86 \%$ \\
Patent withdrawn & 275 & $27.10 \%$ & 287,110 & $30.68 \%$ \\
Grant refused & 51 & $5.02 \%$ & 40,309 & $4.31 \%$ \\
Other loss &. &. & 1,447 & $0.15 \%$ \\
\hline Total & $\mathbf{1 , 9 0 1}$ & $\mathbf{1 0 0 \%}$ & $\mathbf{1 , 2 6 6 , 5 0 6}$ & $\mathbf{1 0 0 \%}$ \\
\hline \hline
\end{tabular}

Table 2: Outcomes of application procedures of business method inventions compared to the total population of applications at the EPO $1978-2003$ (percentages have been calculated excluding pending procedures).

In a Pearson $\chi^{2}$-test the differences between business method and the average patent application turned out to be significant at the $1 \%$ level $\left(\chi^{2}(3)=416.37\right.$ excluding pending cases, $\chi^{2}(4)=417.24$ including pending cases).

\begin{tabular}{r|ccccc}
\hline \hline Patent Applicant & Country & $\begin{array}{c}\text { Appli- } \\
\text { cations }\end{array}$ & $\begin{array}{c}\text { Patents } \\
\text { granted }\end{array}$ & $\begin{array}{c}\text { Oppositions } \\
\text { received }\end{array}$ & $\begin{array}{c}\text { Patents } \\
\text { revoked }\end{array}$ \\
\hline Pitney Bowes & US & 192 & 99 & 67 & 26 \\
IBM Corp. & US & 99 & 46 & 1 & 0 \\
NCR & US & 71 & 20 & 2 & 1 \\
Frankotyp-Postalia & DE & 46 & 11 & 1 & 0 \\
Neopost Ltd. & UK & 45 & 27 & 5 & 2 \\
AT\&T & US & 39 & 11 & 1 & 1 \\
Fujitsu & JP & 37 & 15 & 1 & 1 \\
Hitachi & JP & 35 & 9 & 1 & 1 \\
Sony & JP & 30 & 10 & 0 & 0 \\
Siemens & DE & 24 & 12 & 3 & 2 \\
Matsushita Electr. & JP & 23 & 9 & 0 & 0 \\
Toshiba & JP & 21 & 15 & 4 & 1 \\
Sharp & JP & 20 & 12 & 0 & 0 \\
Sun Microsystems & US & 16 & 5 & 0 & 0 \\
\hline Total & & $\mathbf{7 7 8}$ & $\mathbf{3 4 5}$ & $\mathbf{9 1}$ & $\mathbf{3 7}$ \\
\hline \hline
\end{tabular}

Table 3: Most important patent applicants for business method patents at the European Patent Office 1978 - 2003. 


\begin{tabular}{|c|c|c|c|c|c|c|c|c|c|c|c|c|c|c|}
\hline \multirow[t]{2}{*}{$\begin{array}{c}\text { Application } \\
\text { Year }\end{array}$} & \multicolumn{2}{|c|}{$\begin{array}{l}\text { (1) Duration of } \\
\text { examination }\end{array}$} & \multicolumn{2}{|c|}{$\begin{array}{c}\text { (2) References to } \\
\text { Patents }\end{array}$} & \multicolumn{2}{|c|}{$\begin{array}{l}\text { (3) References to } \\
\text { Non-Patents }\end{array}$} & \multicolumn{2}{|c|}{ (4) Claims } & \multicolumn{2}{|c|}{$\begin{array}{c}\text { (5) PCT } \\
\text { Application }\end{array}$} & \multicolumn{2}{|c|}{$\begin{array}{l}\text { (6) Number of } \\
\text { desg. States }\end{array}$} & \multicolumn{2}{|c|}{$\begin{array}{l}\text { (7) Citations } \\
\text { within } 5 \text { Yrs. }\end{array}$} \\
\hline & BMP & All & BMP & All & BMP & All & BMP & All & BMP & All & BMP & All & BMP & All \\
\hline $\begin{array}{l}1978-1979 \\
\end{array}$ & $3.90^{*}$ & 3.09 & 3.00 & 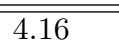 & $1.18^{*}$ & $\bar{~} 0.40$ & 111.45 & 9.44 & 0.18 & $\overline{0.08}$ & 5.18 & 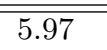 & $1.64^{*}$ & 0.66 \\
\hline $1980-1$ & $5.02 *$ & 3.71 & 3.98 & 3.79 & 0.66 & 0.56 & $13.51^{*}$ & 10.54 & 0.14 & 0.09 & $6.06^{*}$ & 6.88 & $1.90 *$ & 0.81 \\
\hline $1985-1989$ & $5.52^{*}$ & 4.29 & 3.69 & 3.50 & $0.97^{*}$ & 0.78 & $13.14^{*}$ & 11.45 & 0.15 & 0.14 & $6.60^{*}$ & 7.54 & $1.90 *$ & 1.00 \\
\hline $1990-1994$ & $5.36^{*}$ & 4.30 & 3.37 & 3.21 & 1.11 & 0.97 & $17.25^{*}$ & 12.60 & 0.23 & 0.27 & $7.37^{*}$ & 8.11 & $2.49^{*}$ & 1.00 \\
\hline $1995-2000$ & $4.50^{*}$ & 3.91 & $2.21^{*}$ & 2.48 & $0.77^{*}$ & 0.84 & $23.12^{*}$ & 15.39 & 0.51 & 0.48 & 10.78 & 10.72 & $0.83^{*}$ & 0.30 \\
\hline Average & $5.03^{*}$ & 4.08 & $2.68^{*}$ & 2.99 & 0.84 & 0.80 & $20.20 *$ & 13.34 & $0.39^{*}$ & 0.30 & 9.49 & 9.38 & $1.29^{*}$ & 0.64 \\
\hline
\end{tabular}

Table 4: Patent characteristics of patent applications relating to business methods compared to all patent applications at the European Patent Office.

* denotes significant differences at the $5 \%$ level using a Student's t-test on the equality of means. 


\begin{tabular}{r||cc|cc}
\hline \multicolumn{1}{c||}{ Outcomes of Opposition } & \multicolumn{2}{c|}{ BMP } & \multicolumn{2}{c}{ Total } \\
Procedures & Cases & Percent & Cases & Percent \\
\hline Opposition pending & 12 & - & 5,892 & - \\
\hline Revocation of the patent & 40 & $41.67 \%$ & 11,997 & $36.06 \%$ \\
Rejection of the opposition & 27 & $28.13 \%$ & 9,682 & $29.10 \%$ \\
Patent amended & 26 & $27.08 \%$ & 9,129 & $27.44 \%$ \\
Opposition closed & 3 & $3.13 \%$ & 2,461 & $7.38 \%$ \\
\hline Total & $\mathbf{1 0 8}$ & $\mathbf{1 0 0 \%}$ & $\mathbf{3 9 , 1 6 1}$ & $\mathbf{1 0 0 \%}$ \\
\hline \hline
\end{tabular}

Table 5: Outcomes of opposition procedures as of December, $27^{\text {th }}, 2003$ at the European Patent Office. Note that percentages have been calculated excluding procedures still pending.

In a Pearson $\chi^{2}$-test the differences between business method and the average patent application turned out to be not significant at the $5 \%$ level $\left(\chi^{2}(3)=3.251\right.$ excluding pending cases, $\chi^{2}(4)=4.713$ including pending cases). 


\begin{tabular}{r|c|c|c|c|c|c}
\hline \hline Applicant & \multicolumn{2}{|c|}{ Granted EPO Patents } & \multicolumn{2}{|c|}{$\begin{array}{c}\text { US equivalent exists } \\
\text { Opposition } \\
\end{array}$} & Share of all & \multicolumn{2}{c}{$\begin{array}{c}\text { Opposition equivalent in 705 } \\
\text { Ratents }\end{array}$} & $\begin{array}{c}\text { Share of all } \\
\text { Grants }\end{array}$ & $\begin{array}{c}\text { Opposition } \\
\text { Rate }\end{array}$ \\
\hline Pitney Bowes & 312 & $41.35 \%$ & $79.17 \%$ & $40.49 \%$ & $31.73 \%$ & $60.00 \%$ \\
Frankotyp-Postalia & 75 & $5.33 \%$ & $77.33 \%$ & $6.89 \%$ & $14.67 \%$ & $9.09 \%$ \\
Neopost & 144 & $14.58 \%$ & $77.78 \%$ & $9.81 \%$ & $18.75 \%$ & $18.52 \%$ \\
Ascom & 12 & $8.33 \%$ & $83.33 \%$ & $10.00 \%$ & $25.00 \%$ & $0.00 \%$ \\
Frama & 15 & $20.00 \%$ & $100.00 \%$ & $20.00 \%$ & $26.67 \%$ & $25.00 \%$ \\
\hline Total & 588 & $28.31 \%$ & $79.21 \%$ & $26.03 \%$ & $26.67 \%$ & $44.00 \%$ \\
\hline \hline
\end{tabular}

Table 6: US and European patent grants of major producers of franking devices between 1978 and 2003. For European patents the existence of US equivalents and opposition rates are reported.

怤

\begin{tabular}{|c|c|c|c|c|c|c|c|c|c|}
\hline \multirow[b]{2}{*}{ Opponent } & \multirow{2}{*}{$\begin{array}{l}\text { Oppositions } \\
\text { filed }\end{array}$} & \multicolumn{8}{|c|}{ Holder of opposed patents } \\
\hline & & Frankotyp & Fujitsu & Hitachi & NCR & Neopost & Pitney Bowes & Siemens & Toshiba \\
\hline Frankotyp & $38(90)$ & 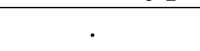 & & & & 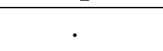 & $38(90)$ & & \\
\hline Gao & $6(23)$ & . & $0(3)$ & $1(1)$ & $0(3)$ & . & . & $0(3)$ & $2(13)$ \\
\hline Giesecke \& Devrient & $16(34)$ & . & $1(4)$ & $1(7)$ & $1(4)$ & . & $0(2)$ & $2(9)$ & $0(8)$ \\
\hline Neopost Ltd. & $18(49)$ & . & . & . & - & . & $18(49)$ & . & . \\
\hline Pitney Bowes & $9(25)$ & $1(4)$ & & . & & $5(18)$ & . & . & . \\
\hline Siemens & $8(197)$ & (') & $0(30)$ & $0(82)$ & $0(2)$ & . & & $0(1)$ & $1(82)$ \\
\hline Société Secap & $9(23)$ & . & . & . & (2) & . & $9(20)$ & . & . \\
\hline $\begin{array}{lc}\text { Total } \\
\end{array}$ & $104(441)$ & $14(4)$ & 1 1(37) & 1 1(90) & $2(9)$ & $5(21)$ & $65(165)$ & $2(13)$ & $\overline{3(103)}$ \\
\hline
\end{tabular}

Table 7: Crosstabulation of opposing and opposed firms at the EPO considering cases on business method patents filed between 1978 and 2003. Note: Figures in brackets denote the total number of opposition filings at the EPO of the opponents. 


\begin{tabular}{|c|c|c|c|c|c|}
\hline $\begin{array}{l}\text { Opposition } \\
\text { occurring }\end{array}$ & $\begin{array}{c}(0) \\
\text { Mean }\end{array}$ & $\begin{array}{c}(1) \\
\mathrm{dF} / \mathrm{dx}\end{array}$ & $\begin{array}{c}(2) \\
d F / d x\end{array}$ & $\begin{array}{c}(3) \\
\mathrm{dF} / \mathrm{dx}\end{array}$ & $\begin{array}{c}(4) \\
\mathrm{dF} / \mathrm{dx}\end{array}$ \\
\hline Claims & 13.17 & $\begin{array}{c}0.0021 \\
(1.07)\end{array}$ & $\begin{array}{l}0.0029 \\
(0.99)\end{array}$ & $\begin{array}{c}0.013 \\
(0.64)\end{array}$ & $\begin{array}{c}0.0015 \\
(0.73)\end{array}$ \\
\hline Ref. to patents & 4.58 & $\begin{array}{c}0.0193^{*} \\
(2.05)\end{array}$ & $\begin{array}{c}0.0193^{*} \\
(2.04)\end{array}$ & $\begin{array}{l}0.0175 \\
(1.84)\end{array}$ & $\begin{array}{c}0.0198^{*} \\
(2.11)\end{array}$ \\
\hline Ref. to non-patents & 0.37 & $\begin{array}{r}-0.0044 \\
(-0.19)\end{array}$ & $\begin{array}{l}-0.0042 \\
(-0.18)\end{array}$ & $\begin{array}{c}-0.0012 \\
(-0.24)\end{array}$ & $\begin{array}{r}-0.0055 \\
(2.33)\end{array}$ \\
\hline Originality & 0.06 & $\begin{array}{r}-0.0261 \\
(-0.22)\end{array}$ & $\begin{array}{r}-0.0276 \\
(-0.23)\end{array}$ & $\begin{array}{l}-0.0500 \\
(-0.24)\end{array}$ & $\begin{array}{r}-0.0151 \\
(-0.13)\end{array}$ \\
\hline Generality & 0.05 & $\begin{array}{c}0.1708 \\
(1.33)\end{array}$ & $\begin{array}{r}0.1620 \\
(1.26)\end{array}$ & $\begin{array}{l}0.1728 \\
(1.35)\end{array}$ & $\begin{array}{r}0.1237 \\
(0.97)\end{array}$ \\
\hline Share X-References & 0.08 & $\begin{array}{c}0.2788^{*} \\
(2.37)\end{array}$ & $\begin{array}{r}0.2810^{*} \\
(2.40)\end{array}$ & $\begin{array}{c}0.2877^{*} \\
(2.45)\end{array}$ & $\begin{array}{c}0.2305^{*} \\
(1.98)\end{array}$ \\
\hline Share A-References & 0.59 & $\begin{array}{l}0.0092 \\
(0.16)\end{array}$ & $\begin{array}{l}0.0103 \\
(0.18)\end{array}$ & $\begin{array}{l}0.0323 \\
(0.54)\end{array}$ & $\begin{array}{l}0.0231 \\
(0.39)\end{array}$ \\
\hline Forward citations & 1.10 & $\begin{array}{l}0.0168 \\
(1.54)\end{array}$ & $\begin{array}{r}0.0176 \\
(1.61)\end{array}$ & $\begin{array}{r}0.0137 \\
(1.27)\end{array}$ & $\begin{array}{r}0.0174 \\
(1.62)\end{array}$ \\
\hline $\mathrm{PCT}_{\text {application }}{ }^{+}$ & 0.02 & $\begin{array}{r}-0.1652 \\
(-1.02)\end{array}$ & $\begin{array}{r}-0.1620 \\
(-1.05)\end{array}$ & $\begin{array}{l}-0.1486 \\
(-0.86)\end{array}$ & $\begin{array}{l}-0.1424 \\
(-0.73)\end{array}$ \\
\hline Total IPC Classes & 1.62 & $\begin{array}{c}0.0479^{*} \\
(2.11)\end{array}$ & $\begin{array}{c}0.0480^{*} \\
(2.11)\end{array}$ & $\begin{array}{c}0.0550^{*} \\
(2.41)\end{array}$ & $\begin{array}{r}0.0416 \\
(1.84)\end{array}$ \\
\hline Designated States & 5.18 & $\begin{array}{r}0.0132 \\
(1.49)\end{array}$ & $\begin{array}{r}0.0131 \\
(1.48)\end{array}$ & $\begin{array}{r}0.0108^{*} \\
(2.22)\end{array}$ & $\begin{array}{r}0.0252^{*} \\
(2.36)\end{array}$ \\
\hline US equivalent exists $^{+}$ & 0.79 & & $\begin{array}{c}-0.0342 \\
(-0.73)\end{array}$ & $\begin{array}{r}-0.0851 \\
(-1.67)\end{array}$ & $\begin{array}{r}-0.0908 \\
(-1.75)\end{array}$ \\
\hline Business Method Patent ${ }^{+}$ & 0.22 & & & $\begin{array}{r}0.1470^{*} \\
(2.92)\end{array}$ & $\begin{array}{r}0.1310^{*} \\
(2.64)\end{array}$ \\
\hline Frankotyp $^{+}$ & 0.13 & & & & $\begin{array}{r}-0.2336^{*} \\
(-4.36)\end{array}$ \\
\hline Neopost ${ }^{+}$ & 0.26 & & & & $\begin{array}{r}-0.1236^{*} \\
(-2.63)\end{array}$ \\
\hline Ascom $^{+}$ & 0.02 & & & & $\begin{array}{r}-0.1951^{*} \\
(-2.08)\end{array}$ \\
\hline Frama $^{+}$ & 0.03 & & & & $\begin{array}{l}-0.1616 \\
(-0.192)\end{array}$ \\
\hline Appl. before $1986^{+}$ & 0.17 & $\begin{array}{c}0.1422^{*} \\
(2.43)\end{array}$ & $\begin{array}{c}0.1461^{*} \\
(2.48)\end{array}$ & $\begin{array}{c}0.1382^{*} \\
(2.34)\end{array}$ & $\begin{array}{c}0.0857 \\
(1.46)\end{array}$ \\
\hline Appl. between 1986/1990 ${ }^{+}$ & 0.25 & $\begin{array}{c}0.1647^{*} \\
(3.52)\end{array}$ & $\begin{array}{c}0.1638^{*} \\
(3.50)\end{array}$ & $\begin{array}{c}0.1607^{*} \\
(3.44)\end{array}$ & $\begin{array}{r}0.1047^{*} \\
(2.16)\end{array}$ \\
\hline Appl. between 1991/1995 & 0.44 & $\begin{array}{c}0.2546^{*} \\
(3.52)\end{array}$ & $\begin{array}{c}0.2529^{*} \\
(3.05)\end{array}$ & $\begin{array}{c}0.2462^{*} \\
(2.94)\end{array}$ & $\begin{array}{c}0.2130^{*} \\
(2.38)\end{array}$ \\
\hline $\begin{array}{l}\text { Observations } \\
\text { LR } \chi^{2} \\
\text { Pseudo } R^{2}\end{array}$ & 554 & $\begin{array}{c}554 \\
117.46 \\
0.1773\end{array}$ & $\begin{array}{c}554 \\
117.99 \\
0.1781\end{array}$ & $\begin{array}{c}554 \\
126.48 \\
0.1910\end{array}$ & $\begin{array}{c}554 \\
159.18 \\
0.2403\end{array}$ \\
\hline
\end{tabular}

Table 8: Probit Models of the incidence of opposition against granted patents. Table shows marginal effects (change in probability for a one unit change in $\mathrm{x}$ ). Z-values of the estimates are given in brackets.

* Significant at the 5\%-level. ${ }^{+}$Discrete variables. 